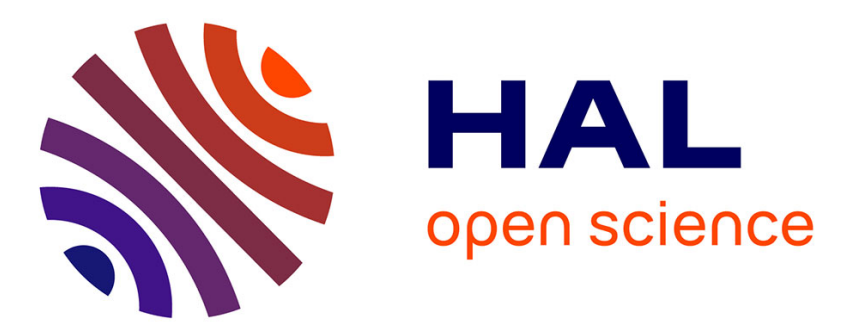

\title{
Solid/liquid extraction as key step for quality assessment of commercial cranberry products using HPTLC-densitometry
}

\author{
Leslie Boudesocque-Delaye
}

\section{- To cite this version:}

Leslie Boudesocque-Delaye. Solid/liquid extraction as key step for quality assessment of commercial cranberry products using HPTLC-densitometry. 7. International Conference on Polyphenols and Health, Oct 2015, Tours, France. , 322 p., 2015, ICPH 2015. hal-01240234

\section{HAL Id: hal-01240234 \\ https://hal.science/hal-01240234}

Submitted on 3 Jun 2020

HAL is a multi-disciplinary open access archive for the deposit and dissemination of scientific research documents, whether they are published or not. The documents may come from teaching and research institutions in France or abroad, or from public or private research centers.
L'archive ouverte pluridisciplinaire HAL, est destinée au dépôt et à la diffusion de documents scientifiques de niveau recherche, publiés ou non, émanant des établissements d'enseignement et de recherche français ou étrangers, des laboratoires publics ou privés. 


\title{
P510
}

\section{A novel tag-free probe for targeting molecules interacted with flavonoid catabolites}

\author{
S. Nakashima*, Z. Liu*, Y. Yamaguchi, S. Saiki, Y. Murata, Y. Nakamura \\ Graduate School of Environmental and Life Science, Okayama University, Okayama700-8530, Japan, \\ yossan@cc.okayama-u.ac.jp \\ *Equally contributed to this work
}

Quercetin is one of the most widely distributed flavonoids in vegetables and fruits and has attracted much attention because of its beneficial biological effect. Quercetin-4'-glycoside (Q4'G) is one of the major quercetin conjugates in onion. Q4' $G$ reaching the colon is subjected to hydrolysis by intestinal bacteria into 3,4-dihydroxyphenylacetic acid (DOPAC), and then DOPAC is converted into 3-hydroxyphenylacetic acid (OPAC) or protocatechuic acid (PCA) in the large intestine. We have reported that DOPAC has the strongest ability to induce expression of phase 2 enzyme genes compared to other metabolites. However, the underlying mechanism in which DOPAC exerts the antioxidant effect via inducing phase 2 enzymes is not clarified. Therefore, developing a new probe of DOPAC give an important clue to reveal the mechanism of its biological activity.

In the present study, to detect directly binding target of DOPAC, we designed a novel DOPAC probe using the copper (I)-catalyzed alken azide 1,3-dipolar cycloaddition (CuAAC) reaction. First, we introduced an alkyne group into DOPAC by esterification with propalgyl alcohol, thereby yielded DOPAC propargyl ester (DPE). To examine its efficacy, DPE was incubated with a model protein, glyceraldehyde-3-phosphate dehydrogenase (GAPDH), and followed by $\mathrm{CuAAC}$ click reaction with azide-labelled biotin. Finally we detected the DOPAC-modified protein by a labelled streptavidin biotinylated antibody (LSAB) method. The formation of 1,2,3-triazole by the Huisgen cycloaddition was also confirmed by both mass spectrometry and nuclear magnetic resonance spectroscopy. These results provide an alternative approach to understand how polyphenol catabolites modify cellular proteins.

Financial support: MEXT KAKENHI Grant Number 25292073.

\section{P511}

\section{Solid/liquid extraction as key step for quality assessment of commercial cranberry products using HPTLC-densitometry.}

Leslie Boudesocque-Delaye

I*Université de Tours, UMR INRA 1282 ISP, 31avenue Monge, 37200 Tours, France, leslie.boudesocque@univ-tours.fr

2 Université de Tours, EA 2106 BBV, 31 avenue Monge, 37200 Tours, France

3 Application Laboratory CAMAG, Sonnenmattstrasse 11, 4132 Muttenz, Switzerland

4 Service Urologie, Hôpital Bretonneau, CHRU de Tours, 37044 Tours cedex 9, France

5 Université de Tours, INSERM U1069 N2C, 31 avenue Monge, 37200 Tours, Franc

Increasing number of dietary supplement containing cranberry polyphenols are commercialized every year. The composition of cranberry ingredients varies from whole fruit powder to cranberry extract or mixture with blueberry. In order to analyze the quality of cranberry based commercial products, researchers proceed to quality control based on BL-DMAC analysis after one step extraction. In our previous work, we demonstrated that BL-DMAC analysis is not sufficient alone to assess the quality of cranberry ingredients. BL-DMAC as quality control couple to High Performance Thin Layer Chromatography -densitometry bring complementary information, especially rate of epicatechin, PAC- $\mathrm{A}_{2}$ and PAC- $\mathrm{B}_{2}$.

In this work, different extraction solvents were screened for extraction of PACs from a range of commercial dietary supplements. Thus, solid / liquid extraction step was repeated until total extraction of polyphenols was achieved, i.e no coloration of the residue in contact with DMAC reagent. If the solvent nature was found to have a minor impact, the number of required extraction steps varied significantly between commercial products. This step was then demonstrated to be a key factor to control for meaningful comparison between various food supplements.

Quality assessment of cranberry extracts was then conducted using both BL-DMAC and HPTLC-densitometry protocols, in order to obtain global PACs content and metabolic profile. A large diversity of PACs global content and profile was observed

This work highlighted the need of new standardization protocols to control and asses the quality of cranberry ingredients, to guarantee biological effect. 


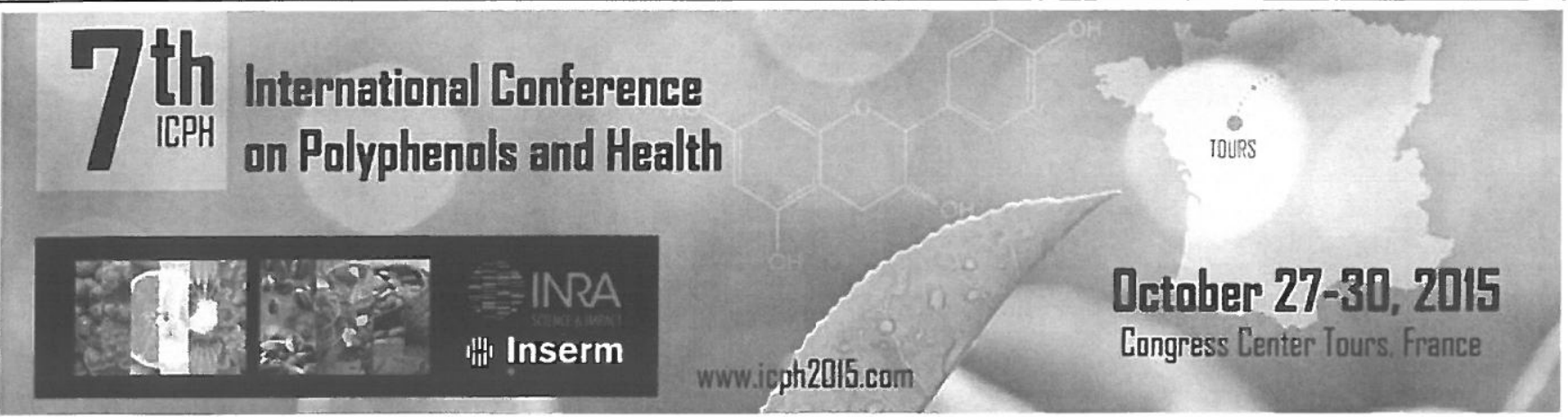

\section{CONTENTS}

Welcoming message

Committees

Program at a glance

Conference center plan

Scientific program

Guidelines for scientific communications

Social program

General information

Sponsors

Invited speaker biographies

Abstracts

Invited lectures

Selected communications

Posters

A: Polyphenol bioavailability and exposure assessment......................... 103

B: Polyphenols in obesity, metabolic syndrome and diabetes ............. 127

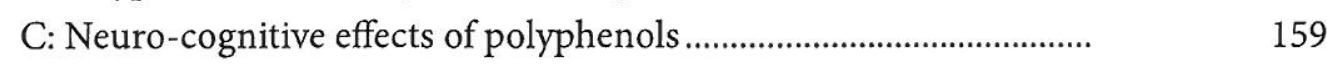

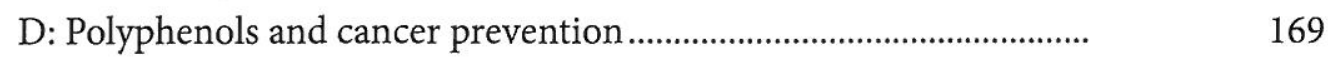

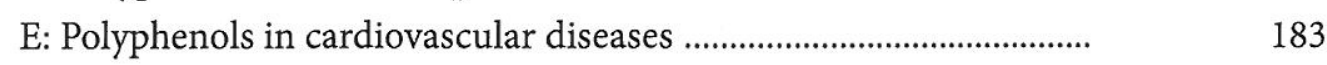

F: Innovative approaches in polyphenol research .................................. 201

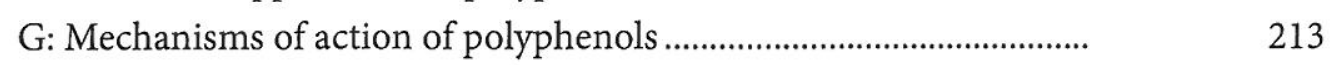

H: Polyphenols and gut Microbiota interactions .................................. 235

I: Polyphenols in other diseases ............................................................. 243

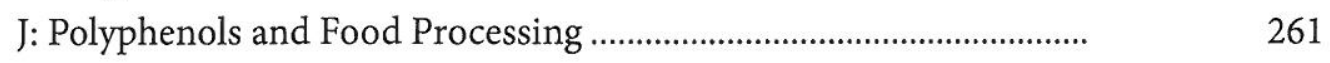

K: Other topics

Authors index

COST Action FA1403 POSITIVe satellite symposium.............................................. 